\title{
RESPON PERTUMBUHAN ANGGREK TEBU (Grammatophyllum speciosum BLUME) SECARA IN VITRO TERHADAP PEMBERIAN BENZYL AMINO PURIN, KINETIN, NAFTALENA ACETIC ACID DAN EKSTRAK PISANG AMBON DALAM MEDIA DASAR SETENGAH MURASHIGE DAN SKOOG
}

(Growth Response Of Cane Orchids (Grammatophyllum speciosum Blume) In Vitro To The Administration Of Benzyl Amino Purines, Kinetin, Naphthalene Acetic Acid And Ambon Banana Extract In Half Basic Media Murashige And Skoog)

\author{
Ellok Dwi Sulichantini ${ }^{1}$, Eliyani ${ }^{2}$, Alvera Prihatini Dewi Nazari ${ }^{2}$, Susylowati ${ }^{2}$, \\ Agusty Saputra ${ }^{2}$ \\ ${ }^{1}$ Laboratorium Kultur Jaringan, Program Studi Agroekoteknologi, Fakultas Pertanian, \\ Universitas Mulawarman, Jalan Pasir Belengkong Kampus Gunung Kelua, Samarinda, \\ Kalimantan Timur, Indonesia. \\ ${ }^{2}$ Program Studi Agroekoteknologi, Fakultas Pertanian, Universitas Mulawarman, \\ Jalan Pasir Belengkong Kampus Gunung Kelua, Samarinda, Kalimantan Timur, Indonesia. \\ Penulis koresponden : ellokds@gmail.com
}

Article Submitted: $16-12-2020$

Article Accepted: 08-01-2021

\begin{abstract}
Kalimantan whose existence is increasingly extinct so it needs to be preserved by in vitro propagation. This study aims to determine the effect of a combination of the growth regulators, Benzyl Amino Purine (BAP), Kinetin, Naphthalene Acetic Acid (NAA), and banana extract on the growth of sugar cane orchids in vitro. The basic media used were Half Murashige and Skoog (1/2 MS), on the base media were added 30 g.L $\mathrm{L}^{-1}$ sugar, 8 g.L $\mathrm{L}^{-1}$ seaweed commercial powder, plus BAP 3 ppm, Kinetin 3 ppm, NAA 0.5 ppm, and ambon banana extract 100 g.L $\mathrm{L}^{-1}$, the acidity $(\mathrm{pH})$ of the media is adjusted to around 5.8. The research design used was a Completely Randomized Design (CRD), each treatment was repeated six times. Data were analyzed using variance analysis and continued with DMRT (Duncan Multiple Range Test) tests with a level of $5 \%$. The results showed that the half media Murashige and Skoog was good for the propagation of sugarcane orchids. The addition of BAP growth regulators, Kinetin, NAA, and banana extracts showed a good response to growth culture. The addition of BAP 3 ppm + NAA $0.5 \mathrm{ppm}$ showed the best results for the height increased, leaf number increased, leaf length increased, leaf width increased, and the number of shots increased. The addition of Ambon banana extract to media containing growth regulators tended to decrease the growth response, seen in the parameters of plant height increased, leaf number increased, leaf length increased, leaf width increased, the number of shoots increased, the number of roots increased and in root length increased.
\end{abstract}

Keywords: Grammatophyllum speciosum Blume, BAP, NAA, Kinetin, Banana Extract

\section{PENDAHULUAN}

Indonesia kaya akan keragaman hayati salah satu diantaranya adalah keanekaragaman jenis anggrek. Anggrek merupakan tanaman hias yang mempunyai potensi untuk dikembangkan karena bernilai ekonomi tinggi, memiliki berbagai bentuk, warna, ukuran dan aroma yang khas serta 
kualitas bunga yang tahan lama (Nurcahyani, dkk., 2007). Anggrek memiliki 25.000 spesies dan 800 genera di dunia (Fauziah, dkk., 2014). Diperkirakan lima puluh persen spesies anggrek terdapat di Papua, sedangkan 2.000 spesies lainnya terdapat di Kalimantan khususnya di Kalimantan Timur dan sisanya tersebar di pulau-pulau lain di Indonesia (Lubis, 2010). Grammatophyllum speciosum Blume yang umum disebut anggrek tebu merupakan salah satu spesies anggrek terbesar dan paling berat di antara jenis-jenis anggrek lainnya.

Anggrek saat ini semakin langka dan terancam punah, salah satu anggrek yang hampir punah adalah dari genus Grammatophyllum. Faktor-faktor seperti terjadinya perubahan atau rusaknya habitat tumbuh akibat penebangan dan konversi lahan merupakan ancaman terhadap kelestarian anggrek alam. Kegiatan pengeksploitasian anggrek dari alam yang dilakukan secara berlebihan dan terus menerus dapat mengakibatkan kepunahan bila tidak diimbangi dengan usaha konservasi. Grammatophyllum speciosum Blume masuk dalam Apendiks II CITES sejak tahun 2005 bersama dengan seluruh jenis anggrek, kecuali dari marga Pahiophedilum (CITES 2005). Anggrek tersebut juga termasuk jenis anggrek yang dilindungi di Indonesia berdasarkan Peraturan Pemerintah Republik Indonesia Nomor 7 Tahun 1999 mengenai jenis-jenis tumbuhan dan satwa yang dilindungi (Anonim, 1999).

Teknik perbanyakan in vitro atau kultur jaringan merupakan salah satu usaha konservasi untuk mencegah kepunahan jenis ini. Teknik tersebut dapat menyediakan tanaman-tanaman baru anggrek alam secara cepat dengan kualitas dan kuantitas yang baik. Teknik perbanyakan secara in vitro beberapa hal, yaitu tidak memerlukan tempat yang luas, dapat digunakan untuk memperbanyak tanaman yang sulit atau lambat diperbanyak secara konvensional, dapat dilakukan sepanjang tahun/tidak mengenal musim, bibit yang dihasilkan lebih sehat dan seragam, perbanyakan tanaman relatif cepat, stok tanaman dapat disimpan dalam waktu yang lama (Gunawan, 1992).

Media kultur merupakan faktor penting dalam penentu keberhasilan perbanyakan tanaman secara kultur jaringan. Media harus berisi semua zat yang dibutuhkan untuk pertumbuhan dan perkembangan suatu eksplan. Selain kondisi aseptik keberhasilan kultur jaringan juga ditentukan oleh media tanam yang digunakan (George, E.F., dan Sherrington. 1984; Gunawan, 1992; Yusnita, 2003). Media tanam yang biasa digunakan dalam kultur jaringan anggrek adalah media Murashige and Skoog (MS) dan Vacin and Went (VW) yang terdiri dari unsur hara makro, unsur hara mikro, dan vitamin sedangkan bahan tambahan lainnya yaitu agar-agar, gula dan zat pengatur tumbuh (zat pengatur tumbuh) (Yusnita dan Handayani, 2011).

Penambahan bahan organik ke dalam media kultur jaringan banyak dilakukan karena umumnya mengandung sumber vitamin, mineral, asam amino, karbohidrat, dan zat pengatur tumbuh yang dapat meningkatkan pertumbuhan dan pembentukan organ tanaman (George, and Klerk, 2008). Pisang merupakan salah satu bahan organik yang dapat ditambahkan dalam media. Kandungan yang terdapat dalam pisang dapat memperbaiki pertumbuhan tanaman (Afriani, 2006). Pada umumnya jenis pisang yang sering digunakan dalam bahan tambahan media kultur jaringan yaitu jenis pisang ambon. Bubur pisang dalam kultur jaringan, menurut Hendaryono (2000) yang biasa digunakan adalah sebanyak 150-200 g. $\mathrm{L}^{-1}$. Penambahan pisang ambon pada media Vacint and Went sebanyak 150 g.L $\mathrm{L}^{-1}$ dapat meningkatkan jumlah tunas anggrek hitam (Untari dan Puspitaningtyas, 2006). Pemberian ekstrak pisang ambon memberikan hasil yang terbaik terhadap 
pertumbuhan tinggi plantlet, jumlah dan luas daun anggrek Dendrobium (Widiastoety dan Purbadi, 2003). Hasil penelitian Arditti dan Ernts (1992) menunjukkan bahwa buah pisang mengandung hormon tumbuh seperti auksin dan giberelin.

Keberhasilan kultur jaringan juga di tentukan oleh pemberian zat pengatur tumbuh. Penggunaan zat pengatur tumbuh di dalam kultur jaringan tergantung pada arah pertumbuhan jaringan tanaman yang diinginkan $^{[13]}$. Ada dua zat pengatur tumbuh yang sering digunakan yaitu auksin dan sitokinin. Zat pengatur tumbuh jenis auksin dapat meningkatkan sintesa protein dengan adanya kenaikan sintesa protein, maka dapat digunakan sebagai sumber tenaga dalam pertumbuhan. Salah satu jenis auksin yang sering digunakan yaitu NAA (Naftaleine Asetat Acid) sedangkan kinetin (6-furfury amino purine) dan BAP (Benzyl Aminopurine) tergolong zat pengatur tumbuh dalam kelompok sitokinin. Sitokinin berfungsi untuk pengaturan pembelahan sel dan morfogenesis. Dalam pertumbuhan jaringan, sitokinin dan auksin jika diberikan secara bersamaan dapat memberikan pengaruh interaksi terhadap deferensiasi jaringan (George dan Sherrington, 1984; Gunawan, 1992; Wiendi, dkk., 1992; Sriyanti dan Wijayani, 1994).

Tujuan Penelitian ini untuk Mengetahui pengaruh kombinasi zat pengatur tumbuh dan penambahan bahan organik ekstrak pisang ambon terhadap pertumbuhan anggrek tebu secara in vitro.

\section{METODOLOGI PENELITIAN}

Penelitian dilaksanakan mulai bulan Desember 2019 sampai April 2020, bertempat di Laboratorium Kultur Jaringan, Fakultas Pertanian, Universitas Mulawarman.

Alat yang digunakan dalam penelitian adalah autoklaf, laminar air flow cabinet, timbangan analitik, kompor gas, hot plate, botol kultur, cawan petri, pipet, gelas ukur berbagai ukuran, pengaduk gelas, bunsen, pinset, skalpel, gunting, hand spayer. Bahan yang digunakan dalam penelitian adalah tunas anggrek tebu hasil kultur in vitro berukuran $1 \mathrm{~cm}$, media dasar Murashige and Skoog setengah konsentrasi (1/2MS), gula, agar-agar 8 g.L $\mathrm{L}^{-1}$, zat pengatur tumbuh Benzyl Aminopurine (BAP), 6-furfury amino purine (kinetin), Naftaleine Asetat Acid (NAA), pisang ambon, Alkohol 70\%, alkohol 95\%, aquades, tissue, spiritus, karet gelang, plastik dan plastik wrap.

Penelitian menggunakan Rancangan Acak Lengkap (RAL) yang terdiri dari enam perlakuan dengan enam ulangan. Data dianalisis menggunakan sidik ragam dan dilanjutkan dengan uji DMRT (Duncan Multiple Range Test) dengan taraf $5 \%$. Perlakuan penelitian adalah sebagai berikut: $\mathrm{m}_{1}=1 / 2 \mathrm{MS}$ $\mathrm{m}_{2}=1 / 2 \mathrm{MS}+$ ekstrak pisang $100 \mathrm{~g} \cdot \mathrm{L}^{-1}$ $\mathrm{m}_{3}=1 / 2 \mathrm{MS}+\mathrm{BAP} 3 \mathrm{ppm}+\mathrm{NAA} 0,5 \mathrm{ppm}$ $\mathrm{m}_{4}=1 / 2 \mathrm{MS}+$ Kinetin $3 \mathrm{ppm}+\mathrm{NAA} 0,5$ ppm

$\mathrm{m}_{5}=1 / 2 \mathrm{MS}+\mathrm{BAP} 3 \mathrm{ppm}+\mathrm{NAA} 0,5 \mathrm{ppm}$ + ekstrak pisang 100 g. $\mathrm{L}^{-1}$

$\mathrm{m}_{6}=1 / 2 \mathrm{MS}+$ Kinetin $3 \mathrm{ppm}+$ NAA 0,50 $\mathrm{ppm}+$ ekstrak pisang $100 \mathrm{~g} . \mathrm{L}^{-1}$

Eksplan yang digunakan adalah tunas steril hasil perbanyakan in vitro berukuran $1 \mathrm{~cm}$. Media dasar yang digunakan adalah media setengah Murashige and Skoog (1/2 MS), ke dalam media ditambahkan gula sebanyak 30 g. $\mathrm{L}^{-1}$, agaragar 8 g.L -1 $^{-1}$, ekstrak pisang dan zat pengatur tumbuh sesuai dengan perlakuan. Derajat keasaman media diukur sekitar 5.8. Kultur diinkubasi pada ruang dengan temperature sekitar $25^{\circ} \mathrm{C}$ dengan pencahayaan lampu TL 1.500 lux selama 24 jam.

Pengamatan dilakukan setiap bulan sampai kultur berumur tiga bulan. Parameter yang diamati: pertambahan tinggi tanaman, pertambahan jumlah daun, panjang daun terpanjang, pertambahan lebar daun yang terlebar, pertambahan jumlah tunas, pertambahan jumlah akar dan 
panjang akar.

\section{HASIL DAN PEMBAHASAN}

Hasil pengamatan menunjukkan bahwa media $1 / 2$ MS baik digunakan untuk meregenerasikan anggrek tebu. Penambahan ekstrak pisang ambon sebanyak 100100 g.L ${ }^{-}$ 1 pada media dasar $1 / 2$ MS memberikan respon pertumbuhan tidak berbeda nyata pada dibandingkan dengan pertumbuhan eksplan pada media $1 / 2$ MS tanpa penambahan ekstrak pisang ambon. Beberapa parameter menunjukkan bahwa pemberian ekstrak pisang ambon memberikan respon pertumbuhan yang lebih rendah dibandingkan dengan media dasar tanpa ekstrak pisang ambon. Pengujian dua jenis zat pengatur tumbuh dari jenis sitokinin yaitu BAP dan Kinetin menunjukkan bahwa pemberian BAP pada konsentrasi 3 ppm memberikan respon pertumbuhan yang lebih baik dibandingkan Kinetin dengan konsentrasi yang sama yaitu 3 ppm. Penambahan ekstrak pisang ambon pada media dengan zat pengatur tumbuh BAP atau Kinetin ditambah dengan NAA ternyata tidak meningkatkan pertumbuhan kultur bahkan cenderung menunjukkan tingkat pertumbuhan yang lebih rendah.

\section{Pertambahan Tinggi Tanaman}

Hasil analisis ragam menunjukkan komposisi media yang digunakan berpengaruh sangat nyata terhadap pertambahan tinggi kultur anggrek tebu umur satu, dua dan tiga bulan setelah inokulasi. Hasil penelitian disajikan pada Tabel 1 memperlihatkan bahwa pada umur satu bulan kultur anggrek tebu sudah menunjukkan adanya pertambahan tinggi dari $0,17-0,40 \mathrm{~cm}$. Pertambahan tinggi tertinggi diperoleh pada kultur yang diinokulasi pada media kontrol ( $1 / 2 \mathrm{MS}), \mathrm{m}_{3}$ $(1 / 2 \mathrm{MS}+\mathrm{BAP} 3 \mathrm{ppm}+\mathrm{NAA} 0,5 \mathrm{ppm}) \mathrm{dan}$ $\mathrm{m}_{5}(1 / 2 \mathrm{MS}+\mathrm{BAP} 3 \mathrm{ppm}+\mathrm{NAA} 0,5 \mathrm{ppm}$ + ekstrak pisang 100 g.L $\mathrm{L}^{-1}$ ). Kultur yang ditanam pada media yang mengandung BAP cenderung menunjukkan respon yang lebih baik daripada kultur yang ditanam pada media dengan zat pengatur tumbuh kinetin. Meskipun keduanya termasuk dalam kelompok sitokinin ternyata BAP memberikan pengaruh lebih besar daripada Kinetin Zat pengatur tumbuh sitokinin berperan dalam pembelahan sel dan morfogenesis (Maryani dan Zamroni, 2005). Hormon sitokinin dan auksin dalam konsentrasi tertentu mampu meningkatkan pertambahan tinggi tanaman. Rasio auksin dan sitokinin dalam media kultur sangat mempengaruhi arah regenerasi eksplan dalam kultur in vitro.

Tabel 1. Pertambahan Tinggi Tanaman pada Kultur Umur 1,2, 3 Bulan (cm)

\begin{tabular}{lccc}
\hline \multirow{2}{*}{ Perlakuan } & \multicolumn{3}{c}{ Umur Kultur (bulan) } \\
\cline { 2 - 4 } $1 / 2 \mathrm{MS}$ & $0,37^{\mathrm{b}}$ & 2 & 3 \\
\hline $1 / 2 \mathrm{MS}+$ Pisang & $0,30^{\mathrm{a}}$ & $0,57^{\mathrm{a}}$ & $1,37^{\mathrm{b}}$ \\
$1 / 2 \mathrm{MS}+$ BAP + NAA & $0,40^{\mathrm{b}}$ & $0,47^{\mathrm{a}}$ & $0,53^{\mathrm{a}}$ \\
$1 / 2 \mathrm{MS}+$ Kinetin + NAA & $0,20^{\mathrm{a}}$ & $0,90^{\mathrm{b}}$ & $1,20^{\mathrm{b}}$ \\
$1 / 2 \mathrm{MS}+$ BAP + NAA + Pisang & $0,37^{\mathrm{b}}$ & $0,40^{\mathrm{a}}$ & $0,97^{\mathrm{ab}}$ \\
$1 / 2 \mathrm{MS}+$ Kinetin + NAA + Pisang & $0,17^{\mathrm{a}}$ & $0,53^{\mathrm{a}}$ & $0,57^{\mathrm{a}}$ \\
\hline
\end{tabular}

Keterangan: Angka yang diikuti oleh huruf yang sama pada kolom yang sama menunjukkan berbeda tidak nyata pada uji DMRT 5\%

\section{Pertambahan Jumlah Daun}

Media Murashige and Skoog merupakan media dasar yang mengandung nutrisi yang lengkap, setengah konsentrasi media MS sudah dapat merikan respon positif terhadap pertambahan jumlah daun 
pada eksplan anggrek tebu. Penambahan ekstrak pisang ambon 100 g.L $\mathrm{L}^{-1}$ pada media menunjukkan jumlah daun yang lebih rendah daripada jumlah daun yang terbentuk pada media tanpa penambahan ekstrak pisang, dapat dilihat pada Tabel 2. Media tanpa ekstrak pisang baik pada perlakuan kontrol, media dengan penambahan zat pengatur tumbuh BAP maupun kinetin memberikan hasil pertambahan jumlah daun yang tinggi, penambahan ekstrak pisang pada media kultur menghasilkan jumlah daun yang lebih rendah daripada jumlah daun yang terbentuk pada media tanpa penambahan ekstrak pisang ambon. Penambahan ekstrak pisang ambon pada media yang mengandung zat pengatur BAP dan kinetin diduga dapat mengubah rasio antara zat pengatur tumbuh eksogen dan endogen menjadi tidak berimbang, sehingga menghambat pertumbuhan kultur.

Respon pertumbuhan kultur pada pertambahan jumlah daun pada Tabel 2, menunjukkan bahwa pada kultur umur satu bulan hasil uji DMRT $5 \%$ menunjukkan bahwa jumlah daun yang tinggi diperoleh pada kultur yang ditanam pada media $1 / 2$ MS (0, 37 helai), 1/2 MS + BAP + NAA (0, 40 helai), dan 1/2 MS + Kinetin + NAA (0,37 helai), (Tabel 2). Pertambahan jumlah daun terbanyak pada umur dua bulan diperoleh pada kultur yang ditanam pada media $1 / 2 \mathrm{MS}+\mathrm{BAP}+\mathrm{NAA}(0,90$ helai $)$ dan $1 / 2$ MS + Kinetin + NAA (0, 90 helai). Pada kultur umur tiga bulan jumlah daun, hasil uji DMRT $5 \%$ menunjukkan bahwa jumlah daun yang tinggi diperoleh pada kultur yang ditanam pada media $1 / 2 \mathrm{MS}$ (1,31 helai), $1 / 2 \mathrm{MS}+\mathrm{BAP}+\mathrm{NAA}(1,20$ helai), dan 1/2 MS + Kinetin + NAA $(0,97$ helai). Bersama-sama dengan auksin, sitokinin merangsang pembelahan sel dan mempengaruhi jalur diferensiasi, penambahan zat pengatur tumbuh dapat mempengaruhi metabolisme RNA yang berperan dalam sintesis protein melalui proses transkripsi molekul RNA, Kenaikan sintesis protein sebagai sumber tenaga yang digunakan untuk pertumbuhan Campbell dan Mitchell, 2003). Jumlah daun yang terbentuk pada setiap eksplan yang ditanam dikendalikan oleh keseimbangan dan interaksi antara zat pengatur tumbuh baik yang terkandung dalam eksplan itu sendiri (endogen) maupun yang diserap dari media (eksogen). Penambahan ekstrak pisang ambon pada media yang digunakan diduga dapat mengubah rasio antara zat pengatur tumbuh eksogen dan endogen menjadi tidak berimbang, sehingga dapat menghambat pertumbuhan, Bersama-sama dengan auksin, sitokinin merangsang pembelahan sel dan mempengaruhi jalur diferensiasi. Menurut (Campbell, 2002). penambahan zat pengatur tumbuh dapat mempengaruhi metabolisme RNA yang berperan dalam sintesis protein melalui proses transkripsi molekul RNA, Kenaikan sintesis protein sebagai sumber tenaga yang digunakan untuk pertumbuhan

Tabel 2. Pertambahan Jumlah Daun pada Kultur Umur 1, 2, 3 Bulan (helai)

\begin{tabular}{lccc}
\hline \multirow{2}{*}{\multicolumn{1}{c}{ Perlakuan }} & \multicolumn{3}{c}{ Umur Kultur (bulan) } \\
\cline { 2 - 4 } $1 / 2$ MS & $1,33^{\mathrm{b}}$ & 2 & 3 \\
\hline $1 / 2 \mathrm{MS}+$ Pisang & $0,00^{\mathrm{a}}$ & $2,00^{\mathrm{a}}$ & $3,33^{\mathrm{b}}$ \\
$1 / 2 \mathrm{MS}+$ BAP + NAA & $1,33^{\mathrm{a}}$ & $2,00^{\mathrm{a}}$ \\
$1 / 2 \mathrm{MS}+$ Kinetin + NAA & $1,33^{\mathrm{b}}$ & $3,33^{\mathrm{b}}$ & $3,67^{\mathrm{b}}$ \\
$1 / 2 \mathrm{MS}+$ BAP + NAA + Pisang & $1,33^{\mathrm{b}}$ & $2,33^{\mathrm{a}}$ & $3,00^{\mathrm{b}}$ \\
$1 / 2 \mathrm{MS}+$ Kinetin + NAA + Pisang & $0,33^{\mathrm{a}}$ & $1,33^{\mathrm{a}}$ & $2,00^{\mathrm{a}}$ \\
\hline
\end{tabular}

Keterangan: Angka yang diikuti oleh huruf yang sama pada kolom yang sama menunjukkan berbeda tidak nyata pada uji DMRT 5\% 


\section{Pertambahan Jumlah Akar}

Hasil pengamatan pada kultur umur

1, 2 dan 3 bulan didapatkan bahwa pertumbuhan akar hanya didapatkan pada perlakuan media $1 / 2 \mathrm{MS}$, media $1 / 2 \mathrm{MS}+$ BAP + NAA, dan media 1/2 MS + Kinetin + NAA sedangkan kultur yang ditanam di media yang diberi tambahan ekstrak pisang, tidak menunjukkan adanya pertumbuhan akar (Tabel 3). Hasil analisis ragam menunjukkan komposisi media yang digunakan berpengaruh sangat nyata terhadap pertambahan tinggi kultur anggrek tebu umur tiga bulan, Jumlah akar tertinggi pada kultur umr 3 bulan dijumpai pada perlakuan $1 / 2$ MS. Hal ini menunjukkan bahwa induksi akar pada kultur anggrek tebu dapat dilakukan dengan menggunakan media $1 / 2$ MS tanpa ditambahan dengan ekstrak pisang maupun zat pengatur tumbuh. Pertambahan jumlah akar juga diperoleh pada kultur yang ditanam pada media yang mengandung BAP + NAA dan Kinetin + NAA (Tabel 3).

Tabel 3. Pertambahan Jumlah Akar pada Kultur Umur 1, 2, 3 Bulan (buah)

\begin{tabular}{lccc}
\hline \multirow{2}{*}{\multicolumn{1}{c}{ Perlakuan }} & \multicolumn{3}{c}{ Umur Kultur (bulan) } \\
\cline { 2 - 4 } & 1 & 2 & 3 \\
\hline $1 / 2$ MS & 0,33 & $1,00^{\mathrm{b}}$ & $2,33^{\mathrm{b}}$ \\
$1 / 2 \mathrm{MS}+$ Pisang & 0,00 & $0,00^{\mathrm{a}}$ & $0,00^{\mathrm{a}}$ \\
$1 / 2 \mathrm{MS}+$ BAP + NAA & 0,33 & $0,33^{\mathrm{a}}$ & $0,67^{\mathrm{a}}$ \\
$1 / 2 \mathrm{MS}+$ Kinetin + NAA & 0,33 & $0,33^{\mathrm{a}}$ & $0,67^{\mathrm{a}}$ \\
1/2 MS + BAP + NAA + Pisang & 0,00 & $0,00^{\mathrm{a}}$ & $0,00^{\mathrm{a}}$ \\
$1 / 2 \mathrm{MS}+$ Kinetin + NAA + Pisang & 0,00 & $0,00^{\mathrm{a}}$ & $0,00^{\mathrm{a}}$ \\
\hline
\end{tabular}

Keterangan: Angka yang diikuti oleh huruf yang sama pada kolom yang sama menunjukkan berbeda tidak nyata pada uji DMRT 5\%

\section{Pertambahan Jumlah Tunas}

Media dasar MS yang digunakan dalam penelitian ini mengandung unsur hara makro, mikro, vitamin dan asam amino yang diperlukan untuk pertumbuhan tunas. Razdan (2003) menyatakan bahwa media MS umum digunakan untuk induksi tunas dan mengandung nutrisi yang sesuai untuk menunjang pertumbuhan optimal dari tanaman secara in vitro. Keistimewaan media MS adalah kandungan nitrat, kalium, dan amonium yang tinggi sehingga sangat efektif untuk partumbuhan beberapa varietas tanaman dikotil dan monokotil (Wetter \& Constabel, 1991). Hasil penelitian menunjukkan bahwa media $1 / 2$ MS dapat digunakan untuk induksi tunas anggrek tebu. Pada kultur umur satu bulan yang ditanam pada media 1/2 MS sudah menunjukkan adanya pertambahan jumlah tunas sebesar
0,67 tunas, pertumbuhan anggrek secara umum sangat lambat termasuk anggrek tebu, pada umur dua bulan jumlah tunas yang terbentuk hanya 1,00 buah dan pada umur tiga bulan sebanyak 1,33 tunas. Menurut George and Sheringgton (1984) dan Wattimena, dkk. (1992), induksi tunas memerlukan konsentrasi auksin yang tinggi dan auksin konsentrasi rendah, demikian pula untuk multiplikasi tunas aksilar diperlukan konsentrasi auksin yang tinggi dan auksin yang rendah. Mondal, dkk., (1990), juga menyatakan bahwa rasio konsentrasi sitokinin dan auksin yang tinggi akan memacu pembentukan tunas. Pertambahan tunas terbanyak ditemukan pada perlakuan $1 / 2 \mathrm{MS}+\mathrm{BAP} 3 \mathrm{ppm}+$ NAA 0,5 ppm sebanyak 1, 67 tunas, pada kultur umur tiga bulan (Tabel 4). 
Tabel 4. Pertambahan Jumlah Tunas pada Kultur Umur 1, 2, 3 Bulan (tunas)

\begin{tabular}{lccc}
\hline \multirow{2}{*}{ Perlakuan } & \multicolumn{3}{c}{ Umur Kultur (bulan) } \\
\cline { 2 - 4 } & 1 & 2 & 3 \\
\hline $1 / 2 \mathrm{MS}$ & $0,67^{\mathrm{ab}}$ & $1,00^{\mathrm{ab}}$ & $1,33^{\mathrm{ab}}$ \\
$1 / 2 \mathrm{MS}+$ Pisang & $0,00^{\mathrm{a}}$ & $1,00^{\mathrm{ab}}$ & $1,00^{\mathrm{a}}$ \\
$1 / 2 \mathrm{MS}+$ BAP + NAA & $1,00^{\mathrm{b}}$ & $1,33^{\mathrm{b}}$ & $1,67^{\mathrm{b}}$ \\
$1 / 2 \mathrm{MS}+$ Kinetin + NAA & $1,00^{\mathrm{b}}$ & $1,33^{\mathrm{b}}$ & $1,33^{\mathrm{ab}}$ \\
$1 / 2 \mathrm{MS}+$ BAP + NAA + Pisang & $0,67^{\mathrm{ab}}$ & $0,67^{\mathrm{a}}$ & $1,00^{\mathrm{a}}$ \\
$1 / 2 \mathrm{MS}+$ Kinetin + NAA + Pisang & $0,67^{\mathrm{ab}}$ & $1,33^{\mathrm{b}}$ & $1,33^{\mathrm{ab}}$ \\
\hline
\end{tabular}

Keterangan: Angka yang diikuti oleh huruf yang sama pada kolom yang sama menunjukkan berbeda tidak nyata pada uji DMRT 5\%

\section{Pertambahan Panjang Daun}

Berdasarkan hasil analisis ragam menunjukkan komposisi media yang digunakan berpengaruh sangat nyata terhadap pertambahan panjang daun pada kultur umur satu bulan dan dua bulan, sedangkan pada kultur umur tiga bulan tidak terdapat perbedaan yang nyata (Tabel 5). Pertambahan panjang daun pada kultur umur satu bulan, menunjukkan bahwa pertumbuhan tertinggi didapatkan pada pada media perlakuan $\mathrm{m}_{3}$ dengan komposisi $1 / 2$ $\mathrm{MS}$ + BAP + NAA $(0,47 \mathrm{~cm})$ meskipun demikian secara statistik diantara perlakuan kontrol (1/2 MS), 1/2 MS + Pisang, 1/2 MS + BAP + NAA, 1/2 MS + Kinetin + NAA, $1 / 2 \mathrm{MS}+\mathrm{BAP}+\mathrm{NAA}+$ Pisang, tidak terdapat perbedaan yang nyata terhadap pertambahan panjang daun pada kultur umur satu bulan. Pertambahan panjang daun pada kultur umur 2 bulan terbaik diperoleh pada kultur yang ditanam pada media $1 / 2 \mathrm{MS}+$ BAP + NAA $(0,87 \mathrm{~cm})$. Pada umur 2 bulan pertambahan panjang daun tidak berbeda nyata diantara perlakuan, kontrol (1/2 MS), 1/2 $\mathrm{MS}+\mathrm{BAP}+\mathrm{NAA}$, dan 1/2 MS + Kinetin + NAA (Tabel 5). Pertambahan panjang daun pada kultur umur 3 bulan tidak terdapat perbedaan yang nyata diantara semua media perlakuan. Penambahan zat pengatur tumbuh dari jenis sitokinin mampu meningkatkan pertumbuhan daun, penambahan ekstrak pisang pada media yang mengandung sitokinin baik BAP maupun kinetin menurunkan tingkat pertambahan panjang daun pada kultur umur satu, dua dan tiga bulan (Tabel 5).

Tabel 5. Pertambahan Panjang Daun pada Kultur Umur 1, 2, 3 Bulan (cm)

\begin{tabular}{lccc}
\hline \multirow{2}{*}{ Perlakuan } & \multicolumn{3}{c}{ Umur Kultur (bulan) } \\
\cline { 2 - 4 } $1 / 2 \mathrm{MS}$ & $0,30^{\mathrm{ab}}$ & 2 & 3 \\
\hline $1 / 2 \mathrm{MS}+$ Pisang & $0,37^{\mathrm{b}}$ & $0,67^{\mathrm{b}}$ & 1,03 \\
$1 / 2 \mathrm{MS}+$ BAP + NAA & $0,47^{\mathrm{b}}$ & $0,87^{\mathrm{b}}$ & 0,60 \\
1/2 MS + Kinetin + NAA & $0,37^{\mathrm{b}}$ & $0,70^{\mathrm{b}}$ & 0,10 \\
1/2 MS + BAP + NAA + Pisang & $0,40^{\mathrm{b}}$ & $0,40^{\mathrm{a}}$ & 0,60 \\
$1 / 2 \mathrm{MS}+$ Kinetin + NAA + Pisang & $0,20^{\mathrm{a}}$ & $0,53^{\mathrm{a}}$ & 0,73 \\
\hline
\end{tabular}

Keterangan: Angka yang diikuti oleh huruf yang sama pada kolom yang sama menunjukkan berbeda tidak nyata pada uji DMRT 5\% 


\section{Pertambahan Lebar Daun}

Perlakuan media tanam ternyata tidak memperlihatkan adanya perbedaan yang nyata terhadap pertambahan lebar daun pada kultur umur satu, dua dan tiga bulan. Pertumbuhan anggrek tebu yang terlihat sangat lambat, pada umur satu bulan, semua perlakuan tidak menyebabkan terjadinya pertambahan lebar daun. Pertambahan lebar daun pada kultur umur dua bulan, hanya terdapat pada perlakuan $1 / 2 \mathrm{MS}+\mathrm{BAP}+\mathrm{NAA}(0,03 \mathrm{~cm})$, sedangkan pada umur tiga bulan pertambahan lebar daun terdapat pada media kontrol $(1 / 2 \mathrm{MS})$ sebesar $(0,07 \mathrm{~cm})$, $1 / 2 \mathrm{MS}+\mathrm{BAP}+\mathrm{NAA}(0,07 \mathrm{~cm}), 1 / 2 \mathrm{MS}$ + Kinetin + NAA $(0,03 \mathrm{~cm}), 1 / 2 \mathrm{MS}+$ Kinetin + NAA + Pisang $(0,07 \mathrm{~cm})$. Arah pertumbuhan daun yang lebih mengarah ke arah memanjang daripada melebar kemungkinan merupakan salah satu penyebab tidak terlihat adanya perbedaan yang nyata terhadap pertambahan lebar daun.

Tabel 6. Pertambahan Lebar Daun pada Kultur Umur 1, 2, 3 Bulan (cm)

\begin{tabular}{lccc}
\hline \multirow{2}{*}{ Perlakuan } & \multicolumn{3}{c}{ Umur Kultur (bulan) } \\
\cline { 2 - 4 } 1/2 MS & 1 & 2 & 3 \\
1/2 MS + Pisang & 0,00 & 0,00 & 0,07 \\
1/2 MS + BAP + NAA & 0,00 & 0,00 & 0,00 \\
1/2 MS + Kinetin + NAA & 0,00 & 0,03 & 0,07 \\
1/2 MS + BAP + NAA + Pisang & 0,00 & 0,00 & 0,03 \\
$1 / 2$ MS + Kinetin + NAA + Pisang & 0,00 & 0,00 & 0,00 \\
\hline
\end{tabular}

Keterangan: Angka yang diikuti oleh huruf yang sama pada kolom yang sama menunjukkan berbeda tidak nyata pada uji DMRT 5\%

\section{Pertambahan Panjang Akar}

Pertambahan panjang akar pada kultur umur satu bulan sudah terlihat pada tiga perlakuan, yaitu kontrol (1/2 MS) sebesar $0,33 \mathrm{~cm}, 1 / 2 \mathrm{MS}+\mathrm{BAP}+\mathrm{NAA}$ $(0,33 \mathrm{~cm})$, dan $1 / 2 \mathrm{MS}+$ Kinetin + NAA $(0,33 \mathrm{~cm})$. Pertambahan panjang akar semakin meningkat pada kultur umur 2 bulan. Pertambahan akar sudah terlihat pada kultur umur dua bulan, tetapi kultur yang diinokulasi pada media 1/2 MS + Pisang, 1/2 $\mathrm{MS}+\mathrm{BAP}+\mathrm{NAA}+$ Pisang, dan $1 / 2 \mathrm{MS}+$ Kinetin + NAA + Pisang masih belum menunjukkan adanya pertambahan panjang akar. Pertambahan panjang akar terpanjang diperoleh pada kultur yang ditanam pada media kontrol $(1 / 2 \mathrm{MS})$, sebesar $2,23 \mathrm{~cm}$. Selain pada media kontrol, pertambahan panjang akar juga diperoleh pada media perlakuan $1 / 2 \mathrm{MS}+\mathrm{BAP}+\mathrm{NAA}$ menghasilkan pertambahan panjang akar sebesar $(0,63 \mathrm{~cm})$, dan 1/2 MS + Kinetin + NAA $(0,33 \mathrm{~cm})$. Kultur yang telah berumur tiga bulan dapat menghasilkan pertambahan panjang akar sebesar 2,97 cm pada media kontrol, 1,37 cm pada media 1/2 MS + BAP + NAA dan sebesar 0,53 pada media $1 / 2$ MS + Kinetin + NAA, sedangkan kultur yang ditanam pada media $1 / 2 \mathrm{MS}+$ Pisang, $1 / 2 \mathrm{MS}+\mathrm{BAP}+\mathrm{NAA}+$ Pisang, dan $1 / 2$ $\mathrm{MS}+$ Kinetin + NAA + Pisang, belum terdapat pertambahan panjang akar. Media $1 / 2$ MS merupakan media dengan komposisi nutrisi yang lengkap sehingga mampu digunakan untuk induksi pertumbuhan akar pada kultur anggrek tebu. Pada umumnya induksi akar memerlukan tambahan zat pengatur dari golongan auksin, misalnya NAA, tetapi pada hasil penelitian ini terlihat bahwa akar kultur dapat tumbuh tanpa tambahan NAA. Penambahan zat pengatur tumbuh dari jenis auksin yaitu BAP sebesar 3 ppm atau Kinetin sebesar 3 ppm dengan ditambah NAA sebesar 0,5 ppm tanpa penambahan ekstrak pisang pada media kultur, juga mampu mendukung 
pertumbuhan akar kultur meskipun hasilnya lebul rendah dari pada pertambahan akar pada media kontrol. Kultur yang ditanam pada media dengan penambahan ekstrak pisang pada media, baik pada media dengan penambahan zat pengatur tumbuh (1/2 MS +
$\mathrm{BAP}+\mathrm{NAA}+$ pisang), maupun pada media $1 / 2 \mathrm{MS}+$ Kinetin + NAA + Pisang, maupun media $1 / 2 \mathrm{MS}+$ pisang tidak menunjukkan pertambahan panjang akar sampai kultur berumur tiga bulan (Tabel 7).

Tabel 7, Pertambahan Panjang Akar pada Kultur Umur 1, 2, 3 Bulan (cm)

\begin{tabular}{lccc}
\hline Perlakuan & \multicolumn{3}{c}{ Umur Kultur (bulan) } \\
\cline { 2 - 4 } & 1 & 2 & 3 \\
\hline 1/2 MS & 0,33 & $2,23^{\mathrm{b}}$ & $2,97^{\mathrm{b}}$ \\
1/2 MS + Pisang & 0,00 & $0,00^{\mathrm{a}}$ & $0,00^{\mathrm{a}}$ \\
1/2 MS + BAP + NAA & 0,33 & $0,63^{\mathrm{a}}$ & $1,37^{\mathrm{a}}$ \\
1/2 MS + Kinetin + NAA & 0,33 & $0,33^{\mathrm{a}}$ & $0,53^{\mathrm{a}}$ \\
1/2 MS + BAP + NAA + Pisang & 0,00 & $0,00^{\mathrm{a}}$ & $0,00^{\mathrm{a}}$ \\
$1 / 2 \mathrm{MS}+$ Kinetin + NAA + Pisang & 0,00 & $0,00^{\mathrm{a}}$ & $0,00^{\mathrm{a}}$ \\
\hline
\end{tabular}

Keterangan: Angka yang diikuti oleh huruf yang sama pada kolom yang sama menunjukkan berbeda tidak nyata pada uji DMRT 5\%

\section{KESIMPULAN}

Media setengah Murashige dan Skoog baik digunakan untuk perbanyakan anggrek tebu. Penambahan zat pengatur tumbuh BAP, Kinetin, NAA dan ekstrak pisang menunjukkan respon yang baik terhadap pertumbuhan kultur. Penambahan zat pengatur BAP $3 \mathrm{ppm}+$ NAA $0,5 \mathrm{ppm}$ menunjukkan hasil yang terbaik terhadap pertambahan tinggi, pertambahan jumlah daun, pertambahan panjang daun, pertambahan lebar daun dan pertambahan jumlah tunas. Penambahan ekstrak pisang ambon pada media yang mengandung zat pengatur tumbuh cenderung menurunkan respon pertumbuhan, terlihat pada parameter pertambahan tinggi tanaman, pertambahan jumlah daun, pertambahan panjang daun, pertambahan lebar daun, pertambahan jumlah tunas, pertambahan jumlah akar dan pertambahan panjang akar.

\section{UCAPAN TERIMA KASIH}

Penelitian ini dibiayai oleh Hibah Penelitian Dosen Fakultas Pertanian Universitas Mulawarman Tahun 2020. Kami menyampaikan ucapan terima kasih kepada Fakultas Pertanian Universitas Mulawarman atas bantuan biaya penelitian yang telah diberikan.

\section{DAFTAR PUSTAKA}

Anonim, 2005. CITES [Convention on International Trade in Endangered Species], 2005, Checklist of CITES species, https: //cites,org/ eng/resources/pub/ checklist08/ Checklist,pdf

Anonim, 1999. Jenis-jenis Tumbuhan dan Satwa yang Dilindungi, Lampiran Peraturan Pemerintah Republik Indonesia Nomor 7 Tahun 1999 Tanggal 27 Januari 1999.

Afriani, A. T., 2006. Penggunaan Gandasil, Air Kelapa dan Ekstrak Pisang pada Perbanyakan Tunas dan Perbesaran Planlet Anggrek Dendrobium (Dendrobium Kanayao) secara In Vitro, Skripsi, Program Studi Hortikultura, Fakultas Pertanian, 
Institut Pertanian Bogor, Bogor, 42 hal.

Arditti, J., and R. Ernts, 1992. Micropropagation of Orchids, Irvine: Departement of Developmental and Cell Biology, University of California.

Arditti, J., 1982. Orchid seed germination and seedling culture-a manual, In: Arditti, J, (ed,), Orchid Biology: Reviews and Perspectives II, Ithaca: Comstock Publishing Associates \& Cornell University Press.

Arditti, J., dan Ernst, R, 1993. Micropropagation of Orchid,John Wiley and Sons, New York.

Campbell Neil A, 2002. Biologi jilid 3, Jakarta: Erlangga.

Fauziah, N., S. A. Aziz, dan D. Sukma, 2014, Karakterisasi morfologi anggrek Phalaenopsis spp, Asli indonesia, Bul,Agrohorti 2 (1): 86-94.

Gunawan, L.W., 1992. Teknik Kultur Jaringan Tumbuhan, Laboratorium Kultur Jaringan Tumbuhan Pusat Antar Universitas (PAU) Bioteknologi IPB, Bogor.

George, E.F., dan Sherrington, 1984. Plant Propagation by Tissue Culture, Handbook and Directory of Directory of Commercial laboratories, Eastern Press, England.

George, E.F., M,A, Hall and G.J. De Klerk, 2008, Plant Propagation By Tissue Culture 3rd Edition Vol 1, Springer, Netherlands, 175 pp.

Hendaryono, D.P.S., 2000. Pembibitan Anggrek dalam Botol, Yogyakarta: Kanisius.
Iswanto, H., 2001. Anggrek Phalaenopsis, Agro media Pustaka, Jakarta.

Lestari, E. G., 2011, Peranan Zat Pengatur Tumbuh dalam Perbanyakan Tanaman Melalui Kultur Jaringan, Jurnal Agrobiogen, 7(1), 63-38.

Lubis, N. N., 2010, Mikropropagasi Tunas Anggrek Hitam (Coelogyne pandurata Lindl) Dengan Pemberian Benzil Amino Purin Dan Naftalen Asam Asetat, Skripsi, Universitas Sumatera Utara, Medan.

Maryani Y, Zamroni, 2005. Penggandaan tunas anggrek melalui kultur jaringan,Jurnal Ilmu Pertanian, 12 : 51 -55 .

Mondal, M., Gupta, S., Mukherjee B.B,, 1990, In Vitro propagation Of Shoot Buds of Carica papaya L, var, HoneyDew, Plant Cell Rep, 8:609612.

Nurcahyani, E., Martha Lulus Lande, Ria Aulia Noviantia, 2017. Induced Resistance of Moon Orchid Planlet (Phalaenopsis amabilis (L,) as Result of The In Vitro Salicylic Acid Selection Toward to Fusarium oxysporum , J, Penelitian Pertanian Terapan, Vol, 17 (2): 132-137.

Paramartha, A.I, Ermavitalini, D, Nurfadilah, S., 2012. Pengaruh Penambahan Kombinasi Konsentrasi ZAT PENGATUR TUMBUH NAA dan BAP Terhadap Pertumbuhan dan Perkembangan Biji Dendrobium taurulinum J,J Smith Secara In Vitro, Jurnal sains dan seni ITS 1(1).

Rahayu, T., 2016, Modul Praktek Kultur Jaringan Tanaman, Surakarta: Universitas Muhammadiyah Surakarta. 
Razdan, M. K., 2003. Introduction Plant Tissue Culture (2sd ed,), USA: Science Publisher

Rodziah, K., Ahmad, L. L., Rokiah, Z., Hafzah, J., 2010. Basal Media for In Vitro Germination of Red-Purple Dragon Fruit (Hylocereus polyrhizus), Agrobiotech vol,1, no, 1, hal, 219-231.

Sriyanti, D,P, dan A,Wijayani, 1994. Teknik Kultur Jaringan, Yayasan Kansius, Yogyakarta.

Untari, R,, dan Puspitaningtyas, D, M, 2006. Pengaruh bahan organik dan NAA terhadap pertumbuhan anggrek hitam (Coelogyne pandurata Lindl,) dalam kultur in vitro, Biodiversitas, 7(3), 344-348.

Wetter, L. R., and Constabel, F., 1991. Metode Kultur Jaringan Tanaman, Mathilda B, Widianto, Penerjemah, Bandung: ITB, Terjemahan dari Plant Tissue Culture Methods.

Wattimena, G. A., L.W. Gunawan, N. S., Matjik, E. Sjamsudin, N. M. A.,
Wiendi, dan A. Eniawati., 1992, Bioteknologi Tanaman, Tim Laboratorium Kultur Jaringan Tanaman, IPB, Bogor.

Widiastoety, D.N., dan Bahar, F.H., 1995, Pengaruh Berbagai Sumber dan Kadar Karbohidrat Terhadap Pertumbuhan Anggrek Dendrobium,Jurnal Hortikultura, vol, 5, no, 5, hal, 76-80.

Widiastoety, D., dan Purbadi, 2003. Pengaruh Bubur Ubi Kayu dan Ubi Jalar terhadap Pertumbuhan Plantlet Anggrek Dendrobium, Journal of Horticultural, 13(1): 1-6.

Yusnita, 2003, Kultur Jaringan, Jakarta: Agro-media Pustaka

Yusnita dan Y, Handayani, 2011. Pengecambahan Bijidan Pertumbuhan Seedling Phalaenopsis Hibridain vitro pada Dua Media Dasar Dengan Atau Tanpa Arang Aktif, Jurnal Agrotropika 16(2): 70-75. 